KOLOM ILMIAH

Social Humaniora

\title{
STUDENTS' PERCEPTIONS OF MOTIVATIONAL TEACHING STRATEGIES IN ENGLISH AS FOREIGN LANGUAGE (EFL) CLASSROOM
}

\author{
Wirentake ${ }^{1}$, Emalia Iragiliati $^{2}$ and Johannes Ananto Prayogo ${ }^{3}$ \\ State University of Malang \\ wirenvanamire@gmail.com
}

\begin{abstract}
This study was aimed at investigating students' perception of motivational teaching strategies in English as Foreign Language (EFL) classroom, specifically on what motivational teaching strategies do students consider important and what are their reasons of considering the strategies as important. This study was a descriptive qualitative study. The instruments employed were questionnaire and interview. Based on the findings, the motivational teaching strategies considered most important are: (1) establish good relationship with students; (2) teachers should bring humors into the classroom; (3) teachers should show their enthusiasm for teaching; (4) teachers should show students that they care about them; (5) teachers should give clear instruction about how to carry a task; (6) teachers should make sure that grades reflect students achievement and effort; (7) teachers should invite English-speaking foreigners to class; (8) teachers should use a short and interesting opening activity to start each class; (9) teachers should avoid social comparison and (10) teachers should be themselves in front of students. In addition, one of the common reasons of why students considered those motivational teaching strategies as important was because they believed that those strategies are able to boost their motivation in learning English if it is implemented by their teachers.
\end{abstract}

Key words: students' perception, motivational teaching strategies, English as Foreign Language (EFL) class

\section{INTRODUCTION}

The people of Indonesia has already been learning English for years, but according to a report by the EF or English First, the English ability of Indonesian people is very low and located in 34th place out of 44 of Asian countries (Kompas, September 21, 2011). Dornyei and Csizer (1998: 208) asserted that there is a possibility that the failure of students in learning any foreign language is caused by the poor teaching quality that students receive in school, which is highly linked with L2 teachers' motivational disposition and teaching commitment.

Chambers (1999: 72) stated that teachers must be able to teach the students with more innovative and creative ways, so that from those ways of teaching, the students will be encouraged and motivated to learn English harder. Further on, Dornyei and Cheng (2007: 153) asserted that in the field of foreign/second language (L2) learning, motivation has long been recognized as one of the key factors that determine L2 achievement and attainment. Therefore, it is fair to say that without sufficient motivation even the brightest learners are unlikely to persist long enough to attain any really useful language proficiency.

To create a motivating-learning situation, the teachers should know and understand motivational teaching strategies. Based on Dornyei (2001: 28-30), motivational strategies are techniques that promote the individual's goal-related behavior. Because human behavior is rather complex, there are many diverse ways of promoting it, in fact, almost any influence a person is exposed to might potentially affect his/her behavior.

The objective of this study is to investigate the students' perceptions of motivational teaching strategies in EFL classroom and the subject of this study is the tenth graders of language program of class $\mathrm{X}$ IBBU of SMAN 8 Malang, in which the total numbers of them are 22 students, consisting 5 males and 17 females. Based on the objective of the study, there are two research problems that the researcher want to investigate, they are:

1. What motivational teaching strategies do the students of EFL consider as important to be implemented by their teachers when they are taught in the class? 
2. What are the EFL students' reasons of selecting certain motivational strategies as important?

\section{METHOD}

The research design of this study was a descriptive qualitative study on students' perception of motivational teaching strategies. The instruments employed in this study were questionnaire and interview, in which questionnaire was employed aimed at revealing the first research problem on what motivational teaching strategies that students considered important to be employed by their teachers, while the interview was conducted in this study in order to find out students' reasons of why do they think that certain motivational teaching strategies as important.

The questionnaire employed in this study was adapted from Dornyei and Csizer (1998) and Dorneyi and Cheng (2007), in which the form of the questionnaire was a close-ended questionnaire. In this questionnaire, the participants were asked to rank the items of motivational teaching strategies from very important, important, less important till least important. The reliability of the questionnaire was administered through a Statistical Product and Service Solutions or SPSS 20, and the score of Cronbach Alpha of the questionnaire was .861. Based on the score, the questionnaire utilized in this study is categorized as reliable instrument.
While for the interview, the questions consist of open-ended questions to reveal the students' reasons.

In analyzing the data of the questionnaire, the researcher in this study followed Horwitz and Young (1991:32) in analyzing Foreign Language Classroom Anxiety Scale (FLCAS) questionnaire to analyze his data, where in that questionnaire, they counted the percentages of each alternative through calculating total respondents selecting each alternative times 100 and divided by total respondents. Based on the percentages, it can be found out which motivational teaching strategies that considered important by the students. While for the interview data, the researcher transcribe the data to analyze and found out students' reasons.

\section{FINDINGS}

There were four main points that were investigated in this study, namely motivational teaching strategies employed by the teacher, important motivational teaching strategies considered by the students and students' reasons of considering the strategies as important.

\section{Employed motivational teaching strategies by the teacher}

The findings of the study found that among those 46 motivational teaching strategies constructed by Dornyei and Cheng (2007), in fact, there were only 32 items employed by the teacher in her teaching and learning experiences. Those employed strategies were gained through a self-assessment. Where in the self-assessment, the teacher was asked to determine of which motivational teaching strategies that she had employed based on her experiences of being a teacher, and for more details, here are the lists of employed teaching strategies by the teacher.

\section{Table 1 Employed motivational teaching strategies by the teacher}

\section{Motivational Teaching Strategies by Teacher}

1. Bring humours to the classroom

2. Show students you care about them

3. Establish good relationship with students

4. Show your enthusiasm for teaching

5. Be yourself in front of students

6. Recognize students' effort and achievement

7. Make sure grades reflect students' achievement and effort

8. Provide students with positive feedback

9. Encourage students to try harder

10. Design tasks that are within the students' ability

11. Encourage students to use English outside the classroom

12. Avoid social comparison 
13. Use a short and interesting opening activity to start each class

14. Give clear instructions about how to carry a task

15. Encourage students to set learning goals

16. Introduce various interesting topics

17. Present various auditory and visual teaching aids

18. Make tasks attractive by including novel and fantasy element

19. Encourage students to create products

20. Make tasks challenging

21. Increase the amount of English you use in the class

22. Encourage students to use English outside the classroom

23. Familiarise students with the cultural background of the target language

24. Remind students of the benefits of mastering English

25. Invite senior students to share their English learning experiences

26. Invite English-speaking foreigners to class

27. Explain the importance of the class rules

28. Allow students to get to know each other

29. Let students suggest class rules

30. Adopt the role of a 'facilitator'

31. Encourage peer teaching and group presentation

32. Give students choices in deciding how and when they will be assessed

As we can see above, those are the 32 motivational teaching strategies that were employed by the teacher during her experiences of becoming a teacher. The researcher believes that those 32 strategies were employed by the teacher because the teacher considers that those strategies are important and effective to be employed when she is teaching. Nugroho (2008) states the motivational teaching strategies that frequently employed by the teachers are indirectly also considered important by the teachers, so that is why then they implement those strategies in their teaching practice.

\section{Important Motivational Teaching Strategies Considered by Students}

In order to answer the first research question on what motivational teaching strategies do students consider important, the researcher then counted the result of the questionnaire through calculating the percentages of respondents selecting each alternative of the questionnaire' items. All percentages of the questionnaire' items are rounded to the nearest whole number.

Table 2 The percentages of students selecting each alternative

NO.

Motivational Teaching Strategies
The table below is the result of the questionnaire and the percentages of students selecting each alternative. In some numbers or items, some students left the items undecided, or they did not choose any option available. Consequently percentages for some items may not add to 100 .

\begin{tabular}{|c|c|c|c|c|c|}
\hline NO. & Motivational Teaching Strategies & 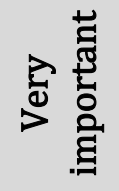 & 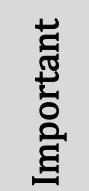 & 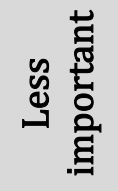 & 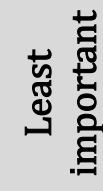 \\
\hline & & \multicolumn{4}{|c|}{ Percentages (\%) } \\
\hline 1. & Teachers should bring humors into the classroom & 73 & 18 & 9 & 0 \\
\hline 2. & Teachers should show students that they care about them & 82 & 14 & 4 & 0 \\
\hline 3. & Teachers should establish good relationship with students & 96 & 0 & 4 & 0 \\
\hline 4. & Teachers should show their enthusiasm for teaching & 64 & 27 & 9 & 0 \\
\hline 5. & Teachers should be themselves in front of students & 46 & 27 & 27 & 0 \\
\hline 6. & Teachers should recognize students' effort and achievement & 32 & 32 & 27 & 9 \\
\hline 7. & $\begin{array}{l}\text { Teachers should make sure that grades reflect students' } \\
\text { achievement and effort }\end{array}$ & 73 & 14 & 9 & 0 \\
\hline 8. & Teachers should provide students with positive feedback & 36 & 36 & 14 & 14 \\
\hline 9. & Teachers should encourage students to study harder & 41 & 23 & 18 & 14 \\
\hline
\end{tabular}




\begin{tabular}{|c|c|c|c|c|c|}
\hline 10. & $\begin{array}{l}\text { Teachers should design tasks that are within the students' } \\
\text { ability }\end{array}$ & 50 & 18 & 32 & 0 \\
\hline 11. & $\begin{array}{l}\text { Teachers should encourage the students to practice their } \\
\text { English and advise them }\end{array}$ & 55 & 9 & 36 & 0 \\
\hline 12. & Teachers should avoid social comparison & 41 & 32 & 27 & 0 \\
\hline 13. & $\begin{array}{l}\text { Teachers should use a short and interesting opening activity } \\
\text { to start each class }\end{array}$ & 41 & 36 & 23 & 0 \\
\hline 14. & $\begin{array}{l}\text { Teachers should give clear instructions about how to carry a } \\
\text { task }\end{array}$ & 59 & 32 & 9 & 0 \\
\hline 15. & Teachers should encourage students to set learning goals & 27 & 32 & 36 & 0 \\
\hline 16. & Teachers should introduce various interesting topics & 45 & 23 & 32 & 0 \\
\hline 17. & $\begin{array}{l}\text { Teachers should present various auditory and visual } \\
\text { teaching aids }\end{array}$ & 32 & 27 & 36 & 4 \\
\hline 18. & $\begin{array}{l}\text { Teachers should make tasks attractive by including novel } \\
\text { and fantasy element }\end{array}$ & 36 & 32 & 32 & 0 \\
\hline 19. & Teachers should encourage students to create products & 14 & 32 & 45 & 9 \\
\hline 20. & Teachers should make tasks challenging & 9 & 59 & 32 & 0 \\
\hline 21. & Teachers should increase the use of English in the class & 23 & 36 & 32 & 9 \\
\hline 22. & $\begin{array}{l}\text { Teachers should encourage students to use English outside } \\
\text { the classroom }\end{array}$ & 41 & 23 & 27 & 9 \\
\hline 23. & $\begin{array}{l}\text { Teachers should familiarize students with the cultural } \\
\text { background of the target language }\end{array}$ & 32 & 27 & 32 & 9 \\
\hline 24. & $\begin{array}{l}\text { Teachers should remind students of the benefits of } \\
\text { mastering English }\end{array}$ & 36 & 19 & 36 & 9 \\
\hline 25. & $\begin{array}{l}\text { Teachers should invite senior students to share their English } \\
\text { learning experiences }\end{array}$ & 18 & 9 & 41 & 32 \\
\hline 26. & Teachers should invite English-speaking foreigners to class & 5 & 22 & 14 & 0 \\
\hline 27. & Teachers should explain the importance of the class rules & 32 & 32 & 36 & 0 \\
\hline 28. & Teachers should allow students to get to know each other & 27 & 32 & 32 & 9 \\
\hline 29. & Teachers should let students suggest class rules & 9 & 59 & 42 & 0 \\
\hline 30. & Teachers should adopt the role of a 'facilitator' & 0 & 55 & 36 & 9 \\
\hline 31. & $\begin{array}{l}\text { Teachers should encourage peer teaching and group } \\
\text { presentation }\end{array}$ & 32 & 27 & 32 & 9 \\
\hline 32. & $\begin{array}{l}\text { Teachers should give students choices in deciding how and } \\
\text { when they will be assessed }\end{array}$ & 36 & 32 & 32 & 0 \\
\hline
\end{tabular}

Based on the result of calculating the percentages of respondents selecting each alternative of the questionnaire' items above, the researcher then tried to reveal the first research problem on what motivational teaching strategies do students considered important, and based on the result, the researcher found out the strategies that students considered most important. Below are the lists of motivational teaching strategies that most of the students considered important.

Table 3 Most Important Strategies Considered by Students

\begin{tabular}{llc}
\hline No. & \multicolumn{1}{c}{ Strategies } & \multicolumn{1}{c}{ Percentages } \\
\hline 1. & Teachers should establish good relationship with students & $96 \%$ \\
2. & Teachers should bring humors into the classroom & $96 \%$ \\
3. & Teachers should show their enthusiasm for teaching & $91 \%$ \\
4. & Teachers should show students that they care about them & $91 \%$ \\
5. & $\begin{array}{l}\text { Teachers should give clear instruction about how to } \\
\text { carry a task }\end{array}$ & $91 \%$ \\
6. & $\begin{array}{l}\text { Teachers should make sure that grades reflect students' } \\
\text { achievement and effort }\end{array}$ & $87 \%$ \\
7. & $\begin{array}{l}\text { Teachers should invite English-speaking foreigners to } \\
\text { the class }\end{array}$ & $81 \%$ \\
8. & $\begin{array}{l}\text { Teachers should use a short and interesting opening activity } \\
\text { to start each class }\end{array}$ & $77 \%$ \\
9. & Teachers should avoid social comparison & $73 \%$ \\
\hline
\end{tabular}


Based on the list above, some strategies are in the same rank, for example; strategies number 1 and 2 are both in the same rank. This happened because the total percentages of students who voted them were exactly the same, namely $96 \%$.
This was also happened to strategies number 3,4 and 5 with total percentages of $91 \%$ and the last was to number 9 and 10 which voted by the same number of students, namely $73 \%$.

\section{Students' Reasons of Considering the Strategies as Important}

Based on the result of the interview, the researcher found that there were some reasons of why students considered some strategies important to be employed by their teacher. For more details, here are the students' reasons of why each strategy is important.

\section{Teachers should establish good relationship with the students}

The reasons of why most of the students considered this strategy important is because they believe that once the teacher could establish a good relationship with them, they can have closer bunch, become friendlier with each other, and the teacher will care to them. Those are some points of the students' reasons when the researcher asked them of why they consider this strategy as an important strategy.

What has been stated by the students above was supported by Pianta (1999), he stated that strong and supportive relationships between teachers and students are fundamental to the healthy development of all students in schools. Therefore, it is no way then the teachers to not having a good relationship with the students, since it is fundamentally needed to create supportive and healthy classroom atmosphere.

\section{Teachers should bring humors into the classroom}

The students' reasons of why they consider this strategy as an important strategy is because they believe that bringing humors into the classroom is needed as an intermezzo to avoid boringness and to make the class to be more exciting. Bryant, et.al (1980) stated that when teachers use humor effectively in the classroom it can result in a number of benefits for teachers and students alike. For example, when teachers use humor they may receive positive student evaluations and find that students are more willing to participate in their classes. While Gorham and Christophel (1990) stated that when students take courses from teachers who use humor they may become more motivated to do well in the class. The experts' statements above strengthening the students reasons that there will be positive effect of bringing humors into the classroom, such as avoiding tediousness and making the class to be more excited or even increasing the students' motivation to learn. Furthermore, jokes seem to have special place for the students to be brought by their teachers in relation with bringing humors into the classroom.

\section{Teachers should show their enthusiasm for teaching}

Some points of the students' reasons of why do they consider this strategy as an important strategy is because they believe that if the teachers are enthusiast, the students are even going to be more enthusiast and they also agreed that enthusiasm for teaching reflects teachers' passion on teaching. So, what has been stated by Csikszentmihalyi (1997: 77) about enthusiastic teachers is supported by the students' reasons. In which he stated that an enthusiastic teacher is a teacher who loves his/her subject matter and who shows her/his passion as if there is nothing else on earth she/he would rather be doing The likeness of the students toward the lesson is depending on the teachers.

\section{Teachers should show students that they care about them}

Based on the interview, the students considered this strategy as an important strategy is because they thought that the teachers need to give them attention and support in order to be motivated to learn harder. Those reasons show us that the students absolutely need to be cared by their teachers, because in order to be motivated, they want their teachers to give them attention when they got some difficulties in studying and to support when they are down. Furthermore, the result of the interview also revealed that most of the students wanting their teachers to be friendly to them to show their cares.

\section{Teachers should give clear instructions about how to carry a task}

Most of the students in general, agreed that a clear instruction will make them easier in doing tasks given by their teachers, and to make 
a clear instruction, the students wanting their teachers to explain every single step of the instruction dealing with the ways how to carry the task and speak clear and louder when they are giving the instructions. As what explained by the researcher beforehand, it is really obvious that unclear instructions may lead the students to confusedness and misleads. The reasons also indicates that giving students clear instructions when they are about to do a task is really important, and according to Dornyei (2001:81) the best way to demonstrate the necessary strategies and skills is to model them. What Dornyei means by that statement in relation with this strategy is that in giving the tasks, it is going to be a lot better for the teachers to give a model for the students in doing the tasks, for example, by pretending to be a student and performing various roles, or by asking volunteers to act out the guidelines.

Teachers should make sure that grades reflect students' achievement and effort

There were some reasons why students considered this strategy as an important strategy to be implemented by their teachers. Most of them considered this strategy as an important strategy because they agreed that they want their teachers to appreciate their effort and hard work that they put in any tasks given, though maybe the result is not good, but as long as they are showing hard work and big effort to be able, then the teachers need to appreciate that or in other words, teachers need to also consider student' effort in giving the grades, and not merely focusing on the achievement. This students' reasons above was also in line with a finding of study conducted by Tippin (2012), where in his study, he investigated a group of 120 undergraduates about what percentage of a grade should be based on performance and what percentage on effort. The students said that $61 \%$ of the grade should be based on performance and $39 \%$ on effort.

\section{Teachers should invite English-speaking} foreigners to class

Most of the students agreed that "inviting English-speaking foreigners to class" is an important strategy that teachers could implement to make them excited and motivated to learn language. Based on the interview conducted, the point of the students' reasons of why the students considered this strategy as an important strategy is because they believed that it can make them to be more motivated and enthusiastic to learn, since they can learn directly not only about the language but also the culture.

Teachers should use a short and interesting opening activity to start each class

Most of the students agreed that starting the class with an interesting activity is an important strategy that teachers could to motivate their students to study harder. Based on the interview, the researcher found that there were some points of the students' reasons that made them considered this strategy as an important strategy. The reasons were because they believe that it will make them to be more excited and motivated to study, besides, it will also be able to make the class atmosphere to be more pleasant so that the students will not be easily feeling bored. And there were some activities that students wanting their teachers to do to start the class based on the result of the interview, they are by starting the class with simple games, jokes and some funny shortstories.

\section{Teachers should avoid social comparison}

The result of the interview showed that there were some reasons of why students considered this strategy as an important strategy. But in general, and based on the reasons, most of the students do not like to be compared to each other. The reasons were because they feel shy and uncomfortable when their teachers compare them. Moreover for the students who feel inferior. And in this case, to implement this strategy, few things that teachers should may not committed based on the interview were try never to compare the students and try to not announcing the score in public space.

\section{Teachers should be themselves in front of students}

The result of the interview showed us that there were some reasons of why students wanting their teachers to be themselves when they are taught in the class. And most of them agreed that because they want to see the authentic version of their teachers. Besides, the students also believe that it will not be interesting for them if the teachers trying to be others. Dornyei (2001) stated that teachers who are always ready to be themselves in front of students are teachers who are willing to admit their weaknesses. The ability to admit one's weaknesses is important due to the fact that in some cultures, teachers are always considered as all-knowing super human. It takes humbleness to be able to do this. 
So, what we can see from students' reasons and Dornyei' statement above, is that teachers are better to be themselves to have their students motivated in learning a language. Besides, a teacher should be brave to admit their weaknesses and not act as if they are allknowing super human.

\section{Discussion}

In this part, the researcher presents the discussion of the study, in which the discussion is organized based on the findings of the study. Teachers should establish good relationship with students

Among those teaching strategies, teachers should establish good relationship is one of the strategies that voted highest among the strategies, namely $96 \%$. This result to the researcher was not really surprising, because even before he distributed the questionnaire, he had already presumed that this strategy would be voted highest among other strategies by the students for some reasons. First, this was due to the personal experience of the researcher when he became a student. At that time, he preferred to have a warm teacher to smart but unsympathetic teacher. Secondly, based on researcher' experience of being a teacher, he also found that the students prefer an emphatic and humorous teacher to smart but show less humanity. This finding is also in accordance with both Hungarian and Taiwanese surveys, suggesting that building a harmonious and trusting rapport with students was considered as fundamentally very important and motivating practice throughout the world. So, what we can see from here is that, developing a good relationship with the students is the obligation of every teacher in order to have a good teaching and learning atmosphere.

In order to be able to develop a personal relationship with the students, Dornyei (2001) proposed three aspects needed by the teachers, namely; acceptance of the students, ability to listen and pay attention to them and availability for personal contact. The three aspects are also supported by other scholars especially in the field of psychology

\section{Teachers should bring humors into the classroom}

$96 \%$ of the student voted this strategy as in important strategy. it indicates that students believed that this strategy could boost their motivation if it is implemented by their teachers in teaching process, and based on the researcher' experience of being a student, he also preferred the humorous teacher rather than a teacher who are too serious, because when his teacher gave joke to the class, the class became more alive and the students were not feeling bored. This was also in accordance with what has been stated by Askildson (2012), he stated that humor is an important element of creating an overall environment conducive to learning, specifically to reduce anxiety or tension, improved approachability of teachers, and increased levels of interest as a result of humor usage. While Kruger (1996) stated that humor is an inextricable part of the human experience and thus a fundamental aspect of humanity's unique capacity for language.

What we can see and summarize form the findings and some theories from experts above on the importance of humors, that humors or making a joke in the classroom is needed to create a pleasant, conducive and supportive classroom atmosphere, as long as we know when and what kind of joke should be given to students.

\section{Teachers should show their enthusiasm for teaching}

The result shows that $91 \%$ of the students considered that showing enthusiasm for teaching is important. According to Csikszentmihalyi (1997: 77), an enthusiastic teacher is a teacher who loves his/her subject matter and who shows her/his passion as if there is nothing else on earth she/he would rather be doing. Such a commitment towards the subject matter then becomes widely-spread among students. He further stated that if a teacher does not believe that in his job, does not enjoy the learning he is trying to transmit, the students will sense this and derive the entirely rational conclusion that particular subject is not worth mastering.

What has been stated by Csikszentmihalyi above was really obvious that in order to be able to motivate students, the teacher need to be always enthusiast in teaching, a teacher who always happy and showing that teaching is really their passion. Those teacher who done that will always be loved and idolized by their students.

Teachers should show students that they care about them

This strategy voted by $91 \%$ of the students. What we can see from this result is that students are always needed to be care of. A teacher who is always care of their students will always win their students heart. Based on my 
experience as a student, there are many ways that actually a teacher could do to show that they care of their students. For example, when I was a student, I felt very happy and enthusiast when my teacher great me saying 'how's your life'. By doing that simple thing, a student will feel that they are cared by their teacher. Everybody know that with a whole class to take care of, a teacher cannot spend too much time with individual students, but by doing that small action which does not need much time, a teacher will always be able to touch the lives of their students.

\section{Teachers should give clear instruction about how to carry a task}

Voted by $91 \%$ of the students, this strategy considered important by the students to be implemented by their teachers to boost their motivation in learning a language, especially when they are taught in the class. This result indicates that giving students clear instructions when they are about to do a task is really important. And it is really obvious that unclear instructions may lead the students to confusedness and misleads. According to Dornyei (2001:81) the best way to demonstrate the necessary strategies and skills is to model them. Teacher can do this, for example, by pretending to be a student and performing various roles, or by asking volunteers to act out the guidelines.

What has been stated by Dornyei above was really enlightening. Because based on my experience, it was true that students will be easier to understand the instructions on how to carry a task, if the teacher modeling them.

Teachers should make sure that grades reflect students' achievement and effort

Voted by $87 \%$ of the students, this strategy was considered as an important strategy by the students. It means that most of the students expect that the grades that their teachers give to them, not only reflect their achievement, but also their effort that they put into it, or in another word, the teacher should be able to be fair and wise in giving the grades to the students.

In dealing with grades, Dornyei (2001: 132-133) proposed some strategies that teachers might implement in order to be able to give the grades that reflect students' achievement and effort, they are: (1) The rating system should be absolutely transparent, that is, it should be obvious right from the start what the success criteria are, (2) When marking written assignments, complement grades with comments that deliver praise and suggestions for improvement, (3) Grades should also reflect, as much as possible, the student's relative improvement rather than only their standard of achievement as compared to some external criterion, (4) Involve students in an ongoing process of evaluation during the course rather than relying on the results of one or two tests only. The assessment should also cover participation in the lessons or in projects, (5) Teacher ratings should be complemented by the students' self-assessment and provide learners with self-evaluation tools, (6) If appropriate, consider developing a system of peer grading (i.e. when students evaluate each other), (7) The final rating of a student should be the product of two-way negotiation, for example by asking each student's opinion in a personal interview or student conference, (8) Rating should be twosided, that is, students should also evaluate the teacher, for example by completing an end-ofterm questionnaire.

Teachers should invite English-speaking foreigners to class

The next strategy that students considered important to be implemented by their teachers when they are taught in the class is "Teachers should invite English-speaking foreigners to class", with $81 \%$ of them voted this strategy. The result indicates that inviting English-speaking foreigners to class can increase students' motivation in learning English. This finding is also in line with researcher' experience when he became a student, where at that time, he always felt motivated and excited when his teacher invited an English-speaking foreigner to class.

There were some reasons why he felt excited and motivated when his teacher invited English-speaking foreigners, firstly, he could practice his English and learned about pronunciation and intonation. Secondly he could learn and asked them about their culture. Pronunciation was one of the things that often made him confused when he tried to talk with any native speaker or English-speaking foreigners, in which that confusedness was never appeared when he talked to his classmate. So, when his teacher invited English-speaking foreigners to class, he was so excited and hoping that he could learn and get use to the way they pronounce the words. And dealing with the culture, at that time till now the researcher always excited to know about other culture, moreover the culture of the language that he is learning. In short, the researcher will always feel 
excited and motivated when talking to native English or English-speaking foreigners, and if we look at the finding, the researcher believes that it also prevail to the students.

Teachers should use a short and interesting opening activity to start each class

Table finding shows that $77 \%$ of the students put this strategy as one of the important motivational teaching strategies that teachers should implement when they are taught in the class. This finding indicates that rather than straightly starting the class with subject matter, it would be better to start the class with an interesting activity that can make the classroom atmosphere to be more relaxed and enjoy. Once the classroom atmosphere is relaxed and pleasant, the researcher believes that the student motivation to learn a language is also going to be increase. Based on the researcher' experience of becoming a student, some shorts and interesting activities are always been able to boost the students' mood to learn. This was happened when one of my teacher always trying to open the class by asking and telling us about some funny jokes and latest news. And that teacher always succeeds to boost my mood and motivation to follow the class.

Teachers should avoid social comparison

Most of the students agreed that "Teachers should avoid social comparison" as one of the important motivational teaching strategies that should be implemented by their teachers, namely $73 \%$ of them voted this strategy. What we can see from this finding is that mostly students do not like to be compared to one another. So, to avoid of making the students to be demotivated, teachers then need to pay attention of this strategy.

As the researcher stated previously, that most of the people do not like to be compared to others, because it is the human nature that we do not like to be compared, especially, when the people or the students to be compared are in the inferior position. There are many teachers that very often trying to compare their students without realizing the negative effects of such behavior might cause. Teachers make comparison with the hope that the less unsuccessful learners will be motivated when they are compared to others, but however, the result are usually are far from the expected one.

There are many researches on the effects of language anxiety on language achievement that has been done in all over the globe for years. The results show that there is a positive correlation between anxiety and language achievements. One source of the anxiety is the fear of being compared with others. It indicates that when teachers are able to avoid social comparison amongst their students, it means that they are able to avoid one of the greatest sources of anxiety (Nugroho, 2008: 58).

Teachers should be themselves in front of students

The last strategy that students considered important to be implemented by their teacher is "Teachers should be themselves in front of students", with $73 \%$ of them voted this strategy. Again, the finding shows that students are expecting their teacher to be themselves or to be what they really are, without trying to be somebody else. Dornyei (2001) stated that teachers who are always ready to be themselves in front of students are teachers who are willing to admit their weaknesses. The ability to admit one's weaknesses is important due to the fact that in some cultures, teachers are always considered as all-knowing super human. It takes humbleness to be able to do this.

What we can take from the finding and Dornyei' statement above, is that teachers are better to be themselves to have their students motivated in learning a language. And a teacher should be brave to admit their weaknesses and not act as if they are all-knowing super human.

\section{Conclusions}

The present study was simply an attempt to describe the motivational teaching strategies that students of language program of X IBBU of SMAN 8 Malang considered motivating to be implemented by their teachers. So, in this study the researcher did not try to make a generalization of the result of the study, but it specifically focus on the needs of the students' of language program of X IBBU of what their teachers should do in order to be motivated in learning a language.

The assertion above is supported by Gardner and Tremblay (1994) who stated that it is very dangerous to make generalization that motivational strategies will be effective and valid in every classroom application. Even Dornyei and Csizer (1998) stressed that no motivational strategy has absolute and general value since such strategies are implemented in dynamically changing and very divers learning contexts. Therefore, in this study, the researcher also did not try to formulate the Ten Commandments as done by Dornyei and Csizer and Cheng, because he assume that by trying to formulate the Ten Commandments, people will 
be trapped into believing that students will be motivated only if those strategies are applied.

There are two research results in this study, they are (1) motivational teaching strategies that students considered important, and (2) students' reasons of considering the motivational teaching strategies as important.

The first result is dealing with the students' perception of motivational teaching strategies. Based on the findings, the motivational teaching strategies that students considered most important are: (1) teachers should establish good relationship with students (96\%); (2) teachers should bring humors into the classroom (96\%); (3) teachers should show their enthusiasm for teaching (91\%); (4) teachers should show students that they care about the students (91\%); (5) teachers should give clear instructions about how to carry a task (91\%); (6) teachers should make sure that grades reflect students achievement and effort (87\%); (7) teachers should invite Englishspeaking foreigners to class (81\%); (8) teachers should use a short and interesting opening activity to start each class (77\%); (9) teachers should avoid social comparison (73\%) and (10) teachers should be themselves in front of students $(73 \%)$. The second result is dealing with the students' reasons of considering the motivational teaching strategies as important. Based on the findings, the researcher found that each strategy was considered important because of some reasons, and those reasons were elaborated and mentioned in the previous chapter. And based on those reasons, the researcher might conclude that one common reason of why students considered those motivational teaching strategies as important is because they believed that if those strategies implemented by their teachers, it will be able to boost their motivation in learning a language. Furthermore, those reasons were also reflected that the students wanting their teachers to understand what they need in order to be motivated in learning a language. In this case, the teachers have to be able to establish good relationship with students, bring humors into the class, showing their enthusiasm for teaching, etc.

\subsection{Suggestions}

In the relation to the findings and discussion, the researchers would like to give several suggestions for several parties such as English teachers, the students, and the future researchers. For the English teachers, the researcher suggest that the teachers are willing to implement those strategies that students considered important in order to make the students to be motivated in learning English. Second, a teacher does not have to be a perfect human being or super human, but they have to be someone who is willing to learn during their life time since their profession demands them to do so. And the last, the teachers must be actively involved in transforming themselves to become a reflective teachers.

For the students, the researcher suggest that the students to be more motivated and critical in learning. It should be noticed that no outside parties can motivate us, if we ourselves have no motivation to succeed. The researcher also recommends the students to try to fall in love with English. Because the researcher believes that once the students love English, the learning would become an enjoyment and will make the students to be easy to master English. The last is that the students should realize that cooperation with the teachers is essentially needed in order to achieve common goals.

For the future researchers, the researcher suggest that they have to use more students as the subject of the study, and it is going to be better to have the subject of the study from more than one or two schools, or they have to widen the scope of the study. Not only that, since this study is only investigating the students' perceptions of motivational teaching strategies, so it would be interesting to conduct a study that investigating not only the students perceptions, but also the teachers perceptions on the importance of those motivational teaching strategies. so that it can be seen the difference perceptions of the teachers and students toward the motivational teaching strategies proposed by Dornyei.

\section{REFERENCES}

Ary, D., Jacobs., Lucy. C. \& Sorensen. 2010. Introduction to Research in Education. Eight Edition. Belmont: Wadsworth.

Brophy, J. E. 2004. Motivating Students to Learn.Second edition. New Jersey: Lawrence Erlbaum. (Online), (http://libgen.org/search.php?req=mot ivating+students+to+learn\&open $=0$ $\&$ view $=$ simple $\&$ phrase $=1 \&$ column $=$ titl e), accessed on August 9, 2014.

Brown, D.H. 2007. Principles of Language LearningandTeaching.Fifthedition. New York : Pearson Education, Inc. 
Bryant, J., Crane, J., Cominsky, P. W., \& Zillmann, D. 1980. Relationship

Between College Teachers' Use of Humor in the Classroom and Students' Evaluations of Their Teachers. Journal of Educational Psychology, (72), 511-519. (Online), (http://www.uab.edu/Communications tudies/richmond

/Richmond\%20Humor\%20in\%20Class room.pdf)

Chambers, G.N. 1999. Motivating Language Learners. Clevedon: Multilingual Matters.

Covington, M.V. 1998. The Will to Learn: A Guide for Motivating Young People. Cambridge: Cambridge University Press.

Csikszentmihalyi, M. 1997. Intrinsic Motivation and Effective Teaching: A Flow Analysis. Baltimore: John Hopkins University Press.

Deci, E.L., \& Ryan, R.M. 1985. Intrinsic Motivation and Self- determination in Human Behavior:NewYork: Plenum.

Dornyei, Z \& Csizer, K. 1998. Ten Commandments for Motivating Language Learners: Results of an Empirical Study.Language Teaching Research 2.(3), 203-229. (Online),(http://www.zoltandornyei.co. uk/uploads/1998-dornyei-csizerltr.pdf), accessed on August 11, 2014.

Dornyei, Z. 2001. Motivational Strategies in Language Classroom. Cambridge: Cambridge University Press.

Dornyei, Z \&Cheng . 2007. The Use of Motivational Strategies in Language Instruction: The Case of EFL Teaching in Taiwan. Innovation in Language Learning and Teaching, (1),153-174. (Online),(http://www.zoltandornyei.co. uk/uploads/2007-cheng-dornyeiillt.pdf).Accessed on August 9, 2014.

Ellis, R. 1997. Second Language Acquisition. Oxford: Oxford University Press.

Finegan, E. 1999. Language: Its Structure and Use. Third Edition. California: Harcourt Brace.

Fraenkel, J. R. \&Wallen, N. E. 2009.Seventh edition. How to Design and Evaluate Research in Education. New York: Mc. Graw Hill.

Gardner, R.C. 1985. Social Psychology and Second Language Learning: The Role of Attitudes and Motivation. London: Edward Arnold.
Gorham, J., \& Christophel, D. M. 1990. The Relationship of Teachers' Use of

Humor in the Classroom to Immediacy and Student Learning. Communication Education. (39), 46-62. (Online), (http://www.jaeonline.org/attachments/article/113/Ve lez_Cano_49_3_76-86.pdf)

Horwitz, E.K and Young, D.J. 1991. Language Anxiety: From Theory and Research to Classroom Implications. New Jersey: Prentice Hall, Inc.

Jhonson, B \& Christensen, L. 2004. Educational Research Quantitative, Qualitative, and Mixed Approaches. Second Edition. USA: Pearson Education, Inc.

Kompas. September 21. 2011. The English Ability of Indonesian People. (Online),(http://edukasi.kompas.com/r ead/2011/09/26/21320318/Kemampu an.Bahasa.Inggris.di.Indonesia.Rendah

Nugroho, R. A. (2008). MotivationlTeachingStrategies Employed by English teachers in Yogyakarta. Taiwan: Ming Chuang University.(Online), (http://ethesys.lib.mcu.edu.tw/ETD$\mathrm{db} /$ ETD-search/getfile?URN=etd1021108-011545\&filename $=$ etd1021108-011545.pdf), accessed on August 17, 2014.

Sugita, M \& Takeuchi. 2010. What can teachers do to motivate their students? A classroom research on motivational strategy use in the Japanese EFL context.Innovation in Language Learning and Teaching, 4.(1), 21-35.

Tippin, G. K., Lafreniere, K. D. and Page, S. (2012). Student perception of

academic grading: Personality, academic orientation, and effort. Active Learning in Higher Education, 13 (1), 51-61. (Online), (http://www.facultyfocus.com/articles /teaching-professor-blog/should-effortcount-students-certainly-think-so/)

Ur, P. 1996. A Course in Language Teaching. Cambridge: Cambridge University Press.

Wlodowski, R. J. 1986. Enhancing Adult Motivation to learn: A comprehensive guide for teaching all adults. CA: JosseyBass 
